\title{
Investigation of Optimum Insulation Thickness for External Walls of Poultry Farms in Bandırma
}

\author{
Asiye Aslan ${ }^{1 *}$ \\ 1*Bandırma Onyedi Eylül University, Gönen Vacational School, Balıkesir, Turkey, (ORCID: 0000-0002-1173-5008), aaslan@bandirma.edu.tr
}

(First received 5 April 2021 and in final form 28 November 2021)

(DOI:10.31590/ejosat.909830)

ATIF/REFERENCE: Aslan, A. (2021). Investigation of Optimum Insulation Thickness for External Walls of Poultry Farms in Bandirma. European Journal of Science and Technology, (27), 890-897.

\begin{abstract}
Poultry farms have an important place in the economy of Bandırma. This study examined the optimum insulation thickness, energy saving, payback period, and $\mathrm{CO}_{2}$ emissions for poultry farms buildings' external walls in Bandırma. Calculations were made according to five different fuels (coal, natural gas, LPG, fuel oil, and electricity) and two different insulation materials (Expanded Polystyrene and Extruded Polystyrene). The Life Cycle Cost method has been applied as the approach. The equilibrium temperature, on which the calculations were based, was the temperature values required by broilers during the 6 -week production season $\left(\mathrm{T}_{\text {base }}=31,29,25\right.$, $23.50,22.50$ and, $20.50^{\circ} \mathrm{C}$ ). The degree day values calculated according to these equilibrium temperatures were obtained as 3111 for heating and 79 for cooling. The results showed that the optimum insulation thickness varied in the range of $0.065-0.233$ in heating. The amount of savings and payback period vary between $17.75-122 \$ / \mathrm{m}^{2}$ and $1.72-1.20$ years, respectively. It was calculated that a reduction by $80-90 \%$ in fuel quantity and $\mathrm{CO}_{2}$ emissions could be achieved when optimum insulation thickness was applied. This study aims to contribute to Bandırma's becoming an important place in the poultry sector.
\end{abstract}

Keywords: Degree days, Energy saving, Optimum insulation thickness, $\mathrm{CO}_{2}$ emission.

\section{Bandırma'da Tavuk Çiftliklerinin Dış Duvarları İçin Optimum Yalıtım Kalınlığının Araştırılması}

\begin{abstract}
$\ddot{O} z$
Bandırma ekonomisinde tavukçuluk tesisleri önemli bir yer tutmaktadır. Bu çalışmada Bandırma'da bulunan tavuk tesisi binaları dış duvarları için optimum yalıtım kalınlığı, enerji tasarrufu, geri ödeme süresi ve $\mathrm{CO}_{2}$ emisyonları araştırılmıştır. Beş farklı yakıta (doğalgaz, kömür, LPG, fuel oil ve elektrik) göre hesaplamalar yapılmıştır. İki farklı yalıtım malzemesi (Expanded Polistren ve Extruded Polistren) kullanılmıştır. Yaşam döngüsü maliyet analizi (LCCA) metodu uygulanmıştır. Hesaplamalarda temel alınan denge sıcaklığı, etlik piliçlerin 6 haftalık üretim sezonu boyunca ihtiyaç duyduğu sıcaklık değerleri $\left(\mathrm{T}_{\text {temel }}=31,29,25,23.50,22.50\right.$ ve $20.50^{\circ} \mathrm{C}$ ) dir. Bu denge sıcaklıklarına göre hesaplanan derece gün değerleri 1sıtma için 3111 , soğutma için 79 olarak elde edilmiştir. Sonuçlarda, optimum yalıtım kalınlığının ısıtmada 0.065-0.233 aralığında değiştiği görülmektedir. Tasarruf miktarı ve geri ödeme

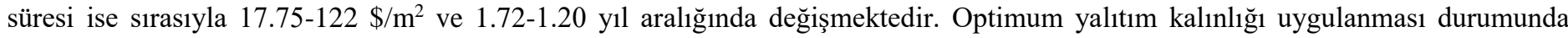
yakıt miktarında ve $\mathrm{CO}_{2}$ emisyonlarında ise \%80-90 oranında azalma sağlanabileceği hesaplanmıştır. Bu çalışma ile Bandırma'nın tavukçuluk sektöründe önemli bir yer kazanmasına katkıda bulunmak amaçlanmıştır.
\end{abstract}

Anahtar Kelimeler: Derece gün, Enerji tasarrufu, Optimum yalıtım kalınlığı, $\mathrm{CO}_{2}$ emisyon.

*Corresponding Author:aaslan@bandirma.edu.tr 


\section{Introduction}

Energy is one of the main inputs for economic and social development. Energy consumption is inevitably growing in parallel with the increasing population, urbanization, industrialization, the expansion of technology and the increase in prosperity. Energy needs to be used in the most economic and efficient way.

Factors affecting productivity in the field of animal husbandry and, especially, in poultry are collected in two groups: genotype and environmental conditions. In environmental conditions, temperature mainly affects both the health and efficiency of animals (Aritürk et al., 1986). When planning the construction of a good poultry coop, factors such as ensuring that the coop is least affected by cold in winter, heat in summer, preventing sudden temperature changes and moisture condensation, ensuring that the appropriate temperature in the coop is maintained should be taken into account (Özdemir and Poyraz, 1997).

Protecting poultrys from the effects of climate and providing the optimal conditions necessary for increasing yields depends on the correct planning and design of coops. Effective provision of the desired environmental conditions in coops throughout the year is possible with isolation (Özdemir and Poyraz, 1997). Heat loss is prevented in winter and heat gain in summer through insulation. It increases comfort by reducing heating and cooling costs. Insulation not only helps maintain the desired temperature level, but also helps control surface perspiration.

In the literature, many studies were conducted to determine the optimum insulation thickness on buildings in Turkey and different countries. Hasan, 1999 calculated the optimum insulation thickness using the life cycle cost analysis method for different structures of wall. It was calculated that wall space can be saved up to $21 \$ / \mathrm{m}^{2}$. The payback period for rock wool and polystyrene was determined in the range of 1-1.7 years and 1.32.3 years, respectively. Kaynakl1, 2008 calculated the optimum insulation thickness for a prototype building in Bursa, Turkey. It was determined that the annual energy needs of the building varied according to various architectural design features. The results showed that the insulation thickness of the optimum varied between 5.3 and $12.4 \mathrm{~cm}$ depending on the fuel types. Natural gas is considered the most suitable fuel for all climate zones in Turkey in terms of costs. The optimum insulation thickness for the external walls was calculated by Uçar and Balo, 2010 for four cities from four different climatic zones in Turkey. Five fuels and four insulation materials were used in the calculations. It was calculated that it could be saved between 4.2 and $9.5 \$ / \mathrm{m}^{2}$. Alsayed and Tayeh, 2019 analyzed the building insulation effects on annual heating and cooling loads in Palestine. Optimum insulation thickness of external walls were calculated based on the use of LPG in winter and electrical energy in summer. Optimum insulation thickness varied between 0.4 and $0.9 \mathrm{~cm}$. Kürekçi, 2016 determined the optimum insulation thickness for 81 cities in Turkey based on the heating and cooling degree days. Calculations were made using four different fuels and three different insulation materials. As a result, net energy savings increased for natural gas, coal, fuel oil, and LPG, respectively, while payback periods were reduced.
Uçar and Usame Dumrul, 2019 calculated the optimum insulation thickness for Malatya city in Turkey for only heating, only cooling, and both heating and cooling situations using three different fuel types (natural gas, coal, and electricity) and two different insulation materials (XPS and EPS) for two different wall models (sheathing and sandwich methods). Consequently, optimum insulation thickness varied between $0.0549 \mathrm{~m}$ and $0.0836 \mathrm{~m}$. Liu et al., 2015 used the P1-P2 economic model to determine the optimum insulation thickness for external walls. For Chengdu, Changsha, and Shaoguan in China, optimum insulation thickness ranged from 0.053 to $0.069 \mathrm{~m}$ when XPS was used, and from 0.081 to $0.105 \mathrm{~m}$ when EPS was used. Axaopoulos et al., 2015 determined the optimum insulation thickness, wind speed, and direction for the external walls within the scope of the heating and cooling period. Wind data in Larnaca, Cyprus were statistically analyzed. It was determined that north-facing walls offered the most economic advantage compared to walls facing other directions. Rakshit et al., 2021 calculated the optimum insulation thickness, annual energy consumption, payback period, and $\mathrm{CO}_{2}$ emissions for typical walls in 25 regions of Ireland. In the study, they reported that the wall type, materials, configuration, insulation type, and the type of heat energy all had significant effects on the annual cost. The calculated optimum insulation thickness in Ireland varied by $30 \%$ as a result of the increase in the number of heating days from low to high. Sabapathy and Gedupudi, 2020 performed an energy-saving analysis by using a numerical analysis for three building shell configurations in five different climate zones of India. The insulating potential of straw, which is an agricultural waste in the context of India's broad climate, was the focus of this study. They concluded that energy savings in the range of $67-96 \%$ can be achieved in the different climatic zones by introducing straw to the outer shell only $10 \mathrm{~cm}$ in thickness. Rosti et al., 2020 determined ideal insulation thickness of the external wall, energy saving, and payback period of investment in all climate zones of Iran. Results revealed that the use of thermal insulation in the block wall, which is one of the common modern walls in Iran, is not economical in some cities.

However, despite many studies in this area, there are almost no studies aimed to specify the optimum insulation thickness for poultry buildings. In this study, the optimum insulation thickness of the external walls was calculated for the poultry farm facilities in Bandirma. The optimum insulation thickness was determined considering the climate of the region in the insulation for the inside temperature of the poultry. The HDD and CDD numbers were calculated using the degree day (DD) method to determine the heating and cooling energy needs. Meteorological data from 2007-2018 were used. Calculations were repeated for 5 different fuels (natural gas, coal, LPG, fuel oil, and electricity) and 2 different insulation materials according to Expanded polystyrene (EPS) and Extruded Polystyrene (XPS). Energy savings, payback periods and $\mathrm{CO}_{2}$ emissions were calculated based on the insulation use.

\section{Material and Method}

\subsection{Heating and cooling degree-days}

Generally, DD is considered one of the simplest methods for energy calculation during heating and cooling buildings (Büyükalaca et al. 2021; Eto, 1988). Degree-days are characterized with the sum of temperature differences between the average outdoor air temperature over a given period of time 
and a known reference temperature. In this study, the number of heating degree days (HDD) and cooling degree days (CDD) in the poultry production period was determined using equations (1) and (2) (Küçüktopçu and Cemek, 2018; De Rosa et al., 2014; Christenson et al. 2006).

$$
\begin{gathered}
\text { For } \mathrm{T}_{\text {out }}<\mathrm{T}_{\text {base }}, \\
H D D=\sum_{1}^{n}\left(T_{\text {base }}-T_{\text {out }}\right) \\
\text { For } \mathrm{T}_{\text {base }}<\mathrm{T}_{\text {out }}, \\
C D D=\sum_{1}^{n}\left(T_{\text {out }}-T_{\text {base }}\right)
\end{gathered}
$$

where $\mathrm{n}$ is the days total number during the period. $\mathrm{T}_{\text {base }}$ and $\mathrm{T}_{\text {out }}$ are the broilers base temperature and the mean temperature of outside air, respectively.

Broiler production time is recommended to be 41 and 42 days for maximum profit. In this study, production for 42 days and downtime and annual rotation were taken as 7 (Table 1). Optimum internal temperature values, which poultrys in poultry need on a weekly basis, are the equilibrium temperature values recommended by researchers for poultry breeding (Table 2).

Table 1. Periods and dates of poultry production (Küçüktopçu and Cemek, 2018; Matzarakis and Balafoutis, 2004).

\begin{tabular}{l|c|c}
\hline Annual rotation & Dates & $\begin{array}{c}\text { Number of } \\
\text { days }\end{array}$ \\
\hline Production 1 & 1 Jan - 11 Feb & 42 \\
Closed & 12 Feb-23 Feb & 12 \\
Production 2 & 24 Feb-6 Apr & 42 \\
Closed & 7 Apr - 18 Apr & 12 \\
Production 3 & 19 Apr -30 May & 42 \\
Closed & 31 May- 11 Jun & 12 \\
Production 4 & 12 Jun-23 Jul & 42 \\
Closed & 24 Jul -4 Aug & 12 \\
Production 5 & 5 Aug - 15 Sep & 42 \\
Closed & 16 Sep -27 Sep & 12 \\
Production 6 & 28 Sep -8 Nov & 42 \\
Closed & 9 Nov- 20 Nov & 12 \\
Production 7 & 21 Nov - 31 Dec & 42 \\
\hline
\end{tabular}

Table 2. Base temperature commended for broilers (Küçüktopçu and Cemek, 2018; Matzarakis and Balafoutis, 2004).

\begin{tabular}{c|c}
\hline Time & T $_{\text {base }}\left({ }^{\circ} \mathbf{C}\right)$ \\
\hline Week 1 & 31.00 \\
Week 2 & 29.00 \\
Week 3 & 25.00 \\
Week 4 & 23.50 \\
Week 5 & 22.50 \\
Week 6 & 20.50 \\
\hline
\end{tabular}

\subsection{Optimum Insulation Thickness on External Walls of Poultry Farms}

Optimum insulation thickness of external walls in buildings varies according to economic criteria such as the number of degree days, outdoor temperature, fuel type, type of thermal insulation material, inflation, and interest rate. In this study, the e-ISSN:2148-2683 life cycle costing analysis (LCCA) method was used for the external walls (Bolattürk, 2008; Şişman et al. 2007). Figure 1 shows the wall structure of the externally insulated poultry plant.

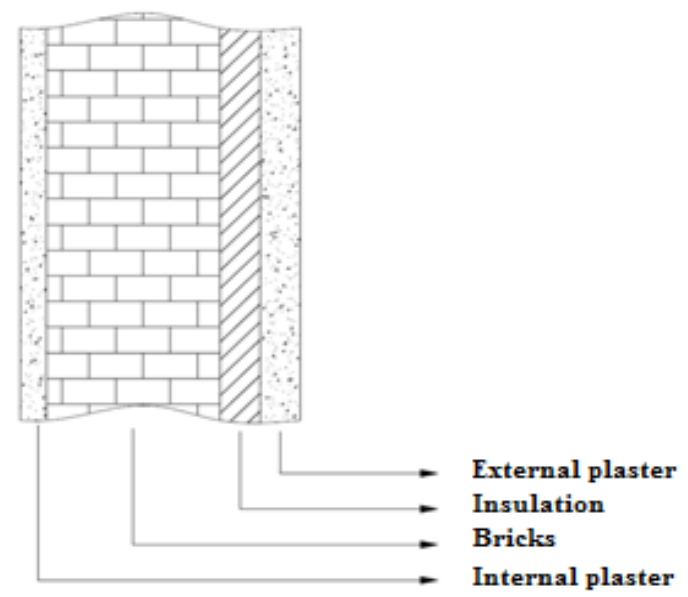

Figure 1.External wall structure.

Table 3 shows the properties and costs of fuels used (natural gas, coal, LPG, fuel oil) in heating and the cost of electricity used in cooling. Table 4 shows the properties of XPS and EPS insulation materials.

Table 3. Properties of fuels and system efficiency (Internet, 2019; Internet 2020a).

\begin{tabular}{l|c|c|c}
\hline \multicolumn{1}{c|}{ Fuel } & Cost & $\begin{array}{c}\text { Lower Heating } \\
\text { Value, Hu }\end{array}$ & $\begin{array}{c}\text { System } \\
\text { Efficiency } \\
\left(\boldsymbol{\eta}_{\mathbf{s}}\right)(\%)\end{array}$ \\
\hline Natural gas & $0.2868 \$ / \mathrm{m}^{3}$ & $34.542 \times 10^{6} \mathrm{~J} / \mathrm{m}^{3}$ & 93 \\
Coal & $0.1921 \$ / \mathrm{kg}$ & $25.122 \times 10^{6} \mathrm{~J} / \mathrm{kg}$ & 65 \\
LPG & $1.75 \$ / \mathrm{kg}$ & $46.442 \times 10^{6} \mathrm{~J} / \mathrm{kg}$ & 88 \\
Fuel-Oil & $0.73 \$ / \mathrm{kg}$ & $41.317 \times 10^{6} \mathrm{~J} / \mathrm{kg}$ & 80 \\
\cline { 3 - 4 } Electricity & $0.1252 \$ / \mathrm{kWh}$ & \multicolumn{2}{|c}{$2.5(\mathrm{COP})$} \\
\hline
\end{tabular}

Table 4. Properties of insulating materials (Internet 2020b).

\begin{tabular}{c|c|c}
\hline Insulation material & $\begin{array}{c}\text { Heat conduction } \\
\text { coefficient, } \boldsymbol{\lambda} \\
\text { (W/mK) }\end{array}$ & $\begin{array}{c}\text { Cost } \\
\mathbf{( \$ )}\end{array}$ \\
\hline XPS (Extruded Polystyrene) & 0.032 & 85 \\
EPS (Expanded Polystyrene) & 0.035 & 50 \\
\hline
\end{tabular}

\subsection{Calculating the Heat Load}

Heat losses in a building occur in the form of heat transfer from building components and in the form of leakage from windows and doors. The heat transfer coefficient $U\left(\mathrm{~W} / \mathrm{m}^{2} \mathrm{~K}\right)$ of a wall that includes an insulation layer is given by:

$$
\mathrm{U}=\frac{1}{\mathrm{R}_{\mathrm{i}}+\mathrm{R}_{\mathrm{w}}+\mathrm{R}_{\mathrm{ins}}+\mathrm{R}_{\mathrm{o}}}
$$

where $R_{i}$ and $R_{o}$ are the inner and outer air-film thermal resistances, respectively. $R_{w}$ is the total thermal resistance of the wall layers without insulation. The thermal resistance of the insulation layer $\mathrm{R}_{\mathrm{ins}}$ is given by:

$\mathrm{R}_{\text {ins }}=\frac{\mathrm{x}}{\lambda}$ 
where $\lambda(\mathrm{W} / \mathrm{mK})$ is the thermal conductivity of the insulation material. $\mathrm{x}(\mathrm{m})$ is the thickness of the insulation material. If $\mathrm{R}_{\mathrm{wt}}$ is the total the wall thermal resistance excluding the insulation layer resistance, equation (3) can be rewritten as:

$$
\mathrm{U}=\frac{1}{\mathrm{R}_{\mathrm{wt}}+\mathrm{R}_{\mathrm{ins}}}
$$

The heat loss from unit surface for external wall:

$$
\mathrm{q}=\mathrm{U} \Delta \mathrm{T}
$$

where $\mathrm{U}$ is the overall heat transfer coefficient. The annual heat losses from unit area can be approximately calculated depending on the degree-days number as the following:

$$
\mathrm{q}_{\mathrm{A}}=86400 \mathrm{DDU}
$$

where DD is the degree days. The annual energy requirement for heating $\left(\mathrm{E}_{\mathrm{A}}\right)$ can be obtained approximately by dividing the annual heat loss to the efficiency of the heating $\operatorname{system}\left(\eta_{\mathrm{s}}\right)$ :

$$
\begin{aligned}
& \mathrm{E}_{\mathrm{A}}=\frac{86400 \mathrm{DD}}{\left(\mathrm{R}_{\mathrm{wt}}+\frac{\mathrm{x}}{\lambda}\right) \eta_{\mathrm{s}}} \\
& \mathrm{m}_{\mathrm{fA}}=\frac{86400 \mathrm{DD}}{\left(\mathrm{R}_{\mathrm{wt}}+\frac{\mathrm{x}}{\lambda}\right) \mathrm{H}_{\mathrm{u}} \eta_{\mathrm{s}}}
\end{aligned}
$$

The annual heating cost $\mathrm{C}_{\mathrm{A}, \mathrm{H}}\left(\$ / \mathrm{m}^{2}\right.$-year) per unit area can be calculated by the equation (10):

$$
\mathrm{C}_{\mathrm{A}, \mathrm{H}}=\frac{86400 \mathrm{HDDC}_{\mathrm{f}}}{\left(\mathrm{R}_{\mathrm{wt}}+\frac{\mathrm{x}}{\lambda}\right) \mathrm{H}_{\mathrm{u}} \eta_{\mathrm{s}}}
$$

where $\mathrm{C}_{\mathrm{f}}$ is fuel cost $(\$ / \mathrm{kg})$ and $\mathrm{H}_{\mathrm{u}}$ is the lower heating value of the fuel $\left(\mathrm{J} / \mathrm{kg} ; \mathrm{J} / \mathrm{m}^{3}\right)$. The annual cooling cost per unit area can be calculated using equation (11). COP is the performance coefficient of the cooling system and it was taken as 2.5 in this study (Kürekçi, 2016):

$\mathrm{C}_{\mathrm{A}, \mathrm{C}}=\frac{86400 \mathrm{CDDC}_{\mathrm{f}}}{\left(\mathrm{R}_{\mathrm{wt}}+\frac{\mathrm{x}}{\lambda}\right) \mathrm{COP}}$

\subsection{Optimum Insulation Thickness Calculation}

The LCC is one of the methods to calculate the optimum insulation thickness. Total heating cost is evaluated together with the present-worth factor PWF for the lifetime of $\mathrm{N}$ years. The PWF depends on the inflation rate (g), and the interest rate (i). According to the interest and inflation rates, PWF is defined as below:

i>g then,

$r=\frac{i-g}{1+g}$

$\mathrm{i}<\mathrm{g}$ then,

$r=\frac{g-i}{1+i}$

$$
\mathrm{PWF}=\frac{(1+r)^{\mathrm{N}}-1}{\mathrm{r}(1+\mathrm{r})^{\mathrm{N}}}
$$

$\mathrm{N}$ life was taken as 10 years and annual inflation $(\mathrm{g})$ and interest (i) rates and were taken as $12.66 \%$ and $8.25 \%$, respectively according to 2020 data (Internet 2020c; Internet 2020d). The total heating cost of the insulated building is given by:

$\mathrm{C}_{\mathrm{t}}=\mathrm{C}_{\mathrm{A}} \mathrm{PWF}+\mathrm{C}_{\mathrm{I}} \mathrm{x}$

or

$$
C_{t}=\frac{86400 \operatorname{HDDC}_{\mathrm{f}} \mathrm{PWF}}{\left(\mathrm{R}_{\mathrm{wt}}+\frac{\mathrm{x}}{\lambda}\right) \mathrm{H}_{\mathrm{u}} \eta_{\mathrm{s}}}+\mathrm{C}_{\mathrm{I}} \mathrm{x}
$$

where $C_{I}$ is the cost of insulation material in $\$ / \mathrm{m}^{3}$ and $\mathrm{x}$ is the insulation thickness in $\mathrm{m}$. The optimum insulation thickness is obtained by minimizing equation (14). Hence, the derivative of $\mathrm{C}_{\mathrm{t}}$ with respect to $\mathrm{x}$ is taken and set equal to zero from which the optimum insulation thickness $\mathrm{x}_{\mathrm{opt}}$ is obtained as:

$\mathrm{x}_{\mathrm{opt}}=293.94\left(\frac{\mathrm{DDC}_{\mathrm{f}} \mathrm{PWF} \lambda}{\mathrm{H}_{\mathrm{u}} \mathrm{C}_{\mathrm{I}} \eta_{\mathrm{s}}}\right)^{1 / 2}-\lambda \mathrm{R}_{\mathrm{wt}}$

\section{5. Environmental Analysis}

The general chemical formula for the combustion of fuels is: as follows:

$$
\begin{aligned}
\mathrm{C}_{\mathrm{k}} \mathrm{H}_{\mathrm{l}} \mathrm{O}_{\mathrm{m}} \mathrm{S}_{\mathrm{p}} \mathrm{N}_{\mathrm{r}}+\alpha \mathrm{A}\left(\mathrm{O}_{2}+3.76 \mathrm{~N}_{2}\right) \\
\rightarrow \mathrm{kCO}_{2}+\frac{1}{2} \mathrm{H}_{2} \mathrm{O}+\mathrm{pSO}_{2}
\end{aligned}
$$

$\mathrm{A}$ and $\mathrm{B}$ can be calculated from the equilibrium formula of oxygen:

$$
\begin{aligned}
& A=k+\frac{l}{4}+p-\frac{m}{2} \\
& B=3.76 \alpha\left(k+\frac{l}{4}+p-\frac{m}{2}\right)+\frac{r}{2}
\end{aligned}
$$

By ignoring $\mathrm{CO}$ and $\mathrm{NOx}$ emissions, the emission amounts obtained by burning one (1) $\mathrm{kg}$ of fuel can be calculated using the equation (16) as follows:

$$
\mathrm{M}_{\mathrm{CO}_{2}}=\frac{\mathrm{kCO}_{2}}{\mathrm{M}} \equiv \mathrm{kgCO}_{2} / \text { kgfuel }
$$

The total amount of $\mathrm{CO}_{2}$ emission can be calculated by placing the total amount of fuel $\left(\mathrm{m}_{\mathrm{fA}}\right)$ within the scope of DD on the right side of the above equation:

$$
\begin{aligned}
\mathrm{M}_{\mathrm{CO}_{2}} & =\frac{44 \mathrm{k}}{\mathrm{M}} \mathrm{m}_{\mathrm{fA}} \\
\mathrm{M}_{\mathrm{CO}_{2}} & =\frac{3801600 \mathrm{DDk}}{\mathrm{M} \eta_{\mathrm{s}} \mathrm{H}_{\mathrm{u}}}\left(\frac{\lambda}{\lambda \mathrm{R}_{\mathrm{wt}}+\mathrm{x}}\right) \mathrm{kg} / \text { year }
\end{aligned}
$$

The molar weight of fuel, $\mathrm{M}$ can be calculated as follows:

$\mathrm{M}=12 \mathrm{k}+\mathrm{l}+16 \mathrm{~m}+32 \mathrm{p}+14 \mathrm{r} \mathrm{kg} / \mathrm{kmol}$

\section{Results and Discussion}

In this study, optimum insulation thickness, energy-saving, and payback period were calculated for the external walls of the poultry plant buildings in Bandirma. The heating and cooling degree day values of the region were calculated using 12-year meteorological data, including 2007-2018, to provide the appropriate internal environment for the poultry breeder. The number of HDD was obtained as 3111 and the number of CDDs as 79 .

Figure 2 identified optimal points where the total cost for heating and cooling loads was achieved as a minimum. The cost of fuel and heating load decreases as the insulation thickness 
increases, while the cost of insulation increases. However, the sum of the cost of fuel and insulation decreases to a point, then increases again. This value, in which the total cost is obtained as a minimum, is the optimal insulation thickness value. When heating was provided using XPS insulation material in
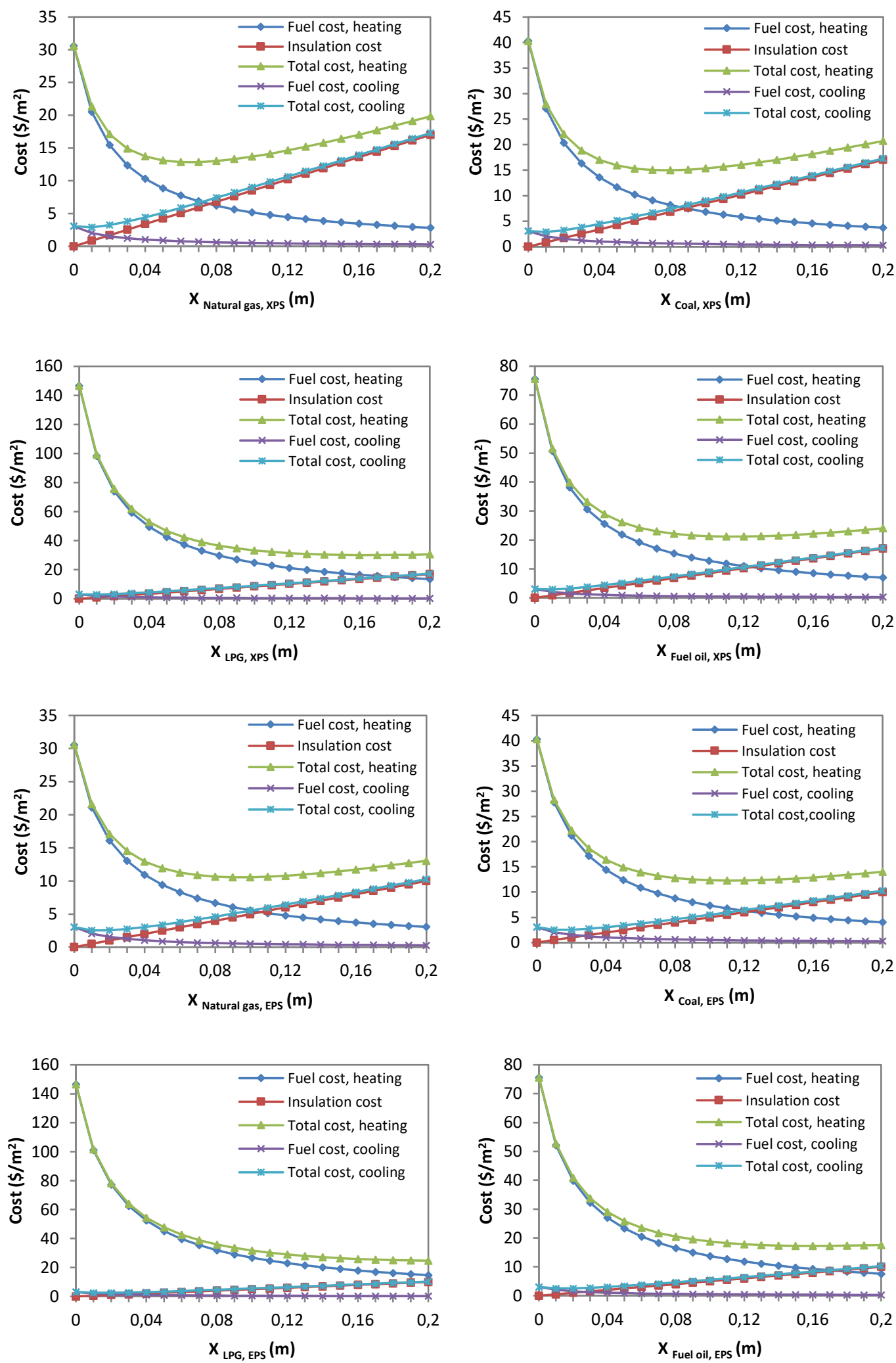

Figure 2. Optimum insulation thickness in heating and cooling. 
Figure 3 shows the effect of annual savings amounts and payback periods for different sources of energy (natural gas, coal, LPG, and fuel oil) on insulation thickness when XPS and
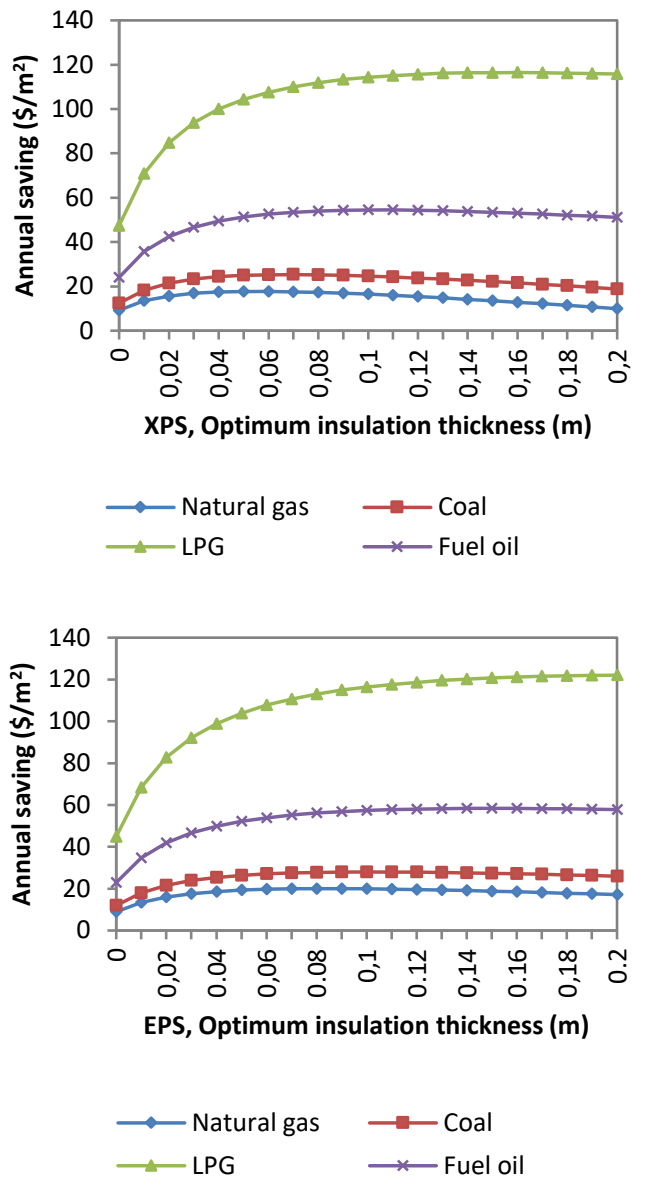

EPS insulation material were used in heating. When LPG was used as the fuel type, more saving and the shortest repayment period were achieved due to its high cost.
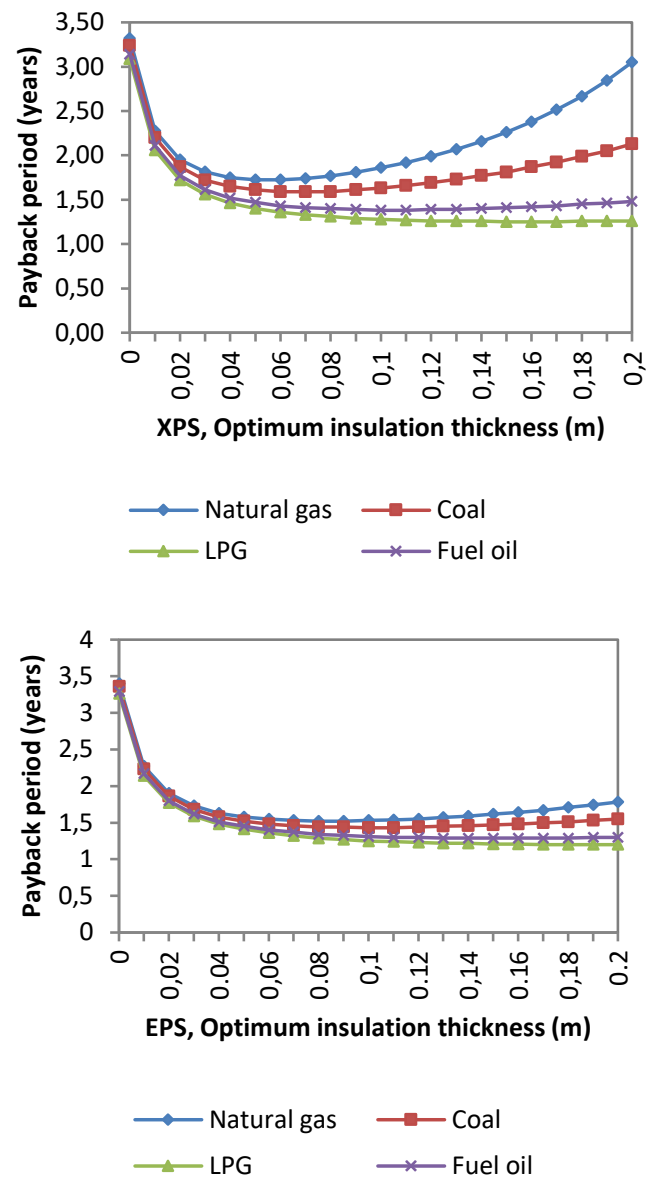

Figure 3. Annual savings and payback period versus on insulation thickness.

Table 5 shows the values recorded at the optimum point. The table shows the energy-saving amount calculated from the unit area and the payback time values when optimum insulation thickness was applied for various insulation materials and fuel types on the external walls. When the table is examined, the optimum insulation thickness differs based on the use of insulation materials (XPS and EPS) in heating (natural gas, coal, LPG and fuel oil) and cooling (electricity). As expected, the highest saving and the shortest payback period were achieved in the same situation. The most savings and shortest repayment period were achieved when EPS and LPG were used in heating, while the lowest savings and longest repayment period were achieved when XPS and natural gas were used. In cooling, the most saving and the shortest payment period were achieved when using EPS insulation material. The payback period was more than 10 years when XPS was used for cooling.

Table 5. Optimum values, savings and payback period in heating and cooling.

\begin{tabular}{|c|c|c|c|c|}
\hline $\begin{array}{c}\text { Insulation } \\
\text { material }\end{array}$ & Fuel & $\begin{array}{l}\mathbf{X}_{\text {opt }} \\
(\mathbf{m})\end{array}$ & $\begin{array}{c}\text { Energy saving } \\
\left(\$ / \mathbf{m}^{2}\right)\end{array}$ & $\begin{array}{c}\text { Payback period } \\
\text { (years) }\end{array}$ \\
\hline \multicolumn{5}{|c|}{ Heating } \\
\hline \multirow{4}{*}{ XPS } & Natural gas & 0.065 & 17.75 & 1.72 \\
\hline & Coal & 0.077 & 25.31 & 1.59 \\
\hline & LPG & 0.167 & 116.49 & 1.25 \\
\hline & Fuel oil & 0.114 & 54.47 & 1.38 \\
\hline \multirow{4}{*}{ EPS } & Natural gas & 0.094 & 20.01 & 1.52 \\
\hline & Coal & 0.111 & 28.00 & 1.43 \\
\hline & LPG & 0.233 & 122.00 & 1.20 \\
\hline & Fuel oil & 0.161 & 58.38 & 1.29 \\
\hline \multicolumn{5}{|c|}{ Cooling } \\
\hline XPS & Electricity & 0.006 & 0.186 & $>10$ \\
\hline EPS & Electricity & 0.014 & 0.479 & 6.37 \\
\hline
\end{tabular}


Figure 4 shows a comparison of annual savings per unit area. The figure shows the change in annual saving based on degree day value for different energy sources when XPS and
EPS insulation materials were used. As degree days, the amount of savings increased.

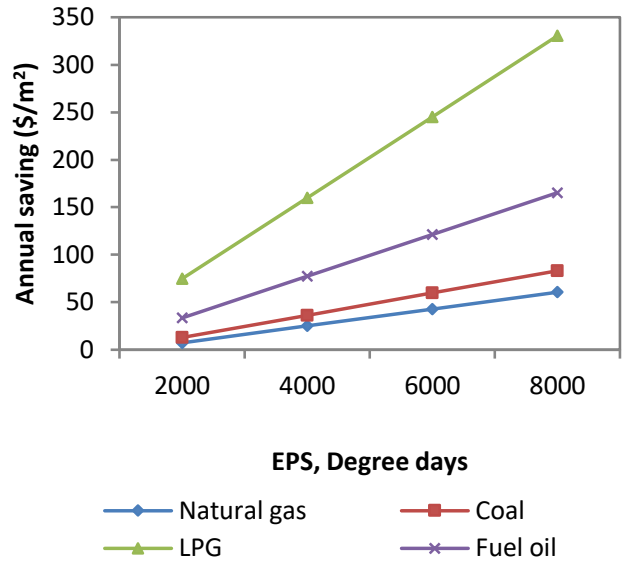

Figure 4. Annual savings versus degree days for different energy sources.

Figure 5 shows the annual fuel consumption in heating and changes in $\mathrm{CO}_{2}$ based on the insulation thickness of gases. When insulation thickness increases, annual fuel consumption and emissions of gases released to the environment decrease.
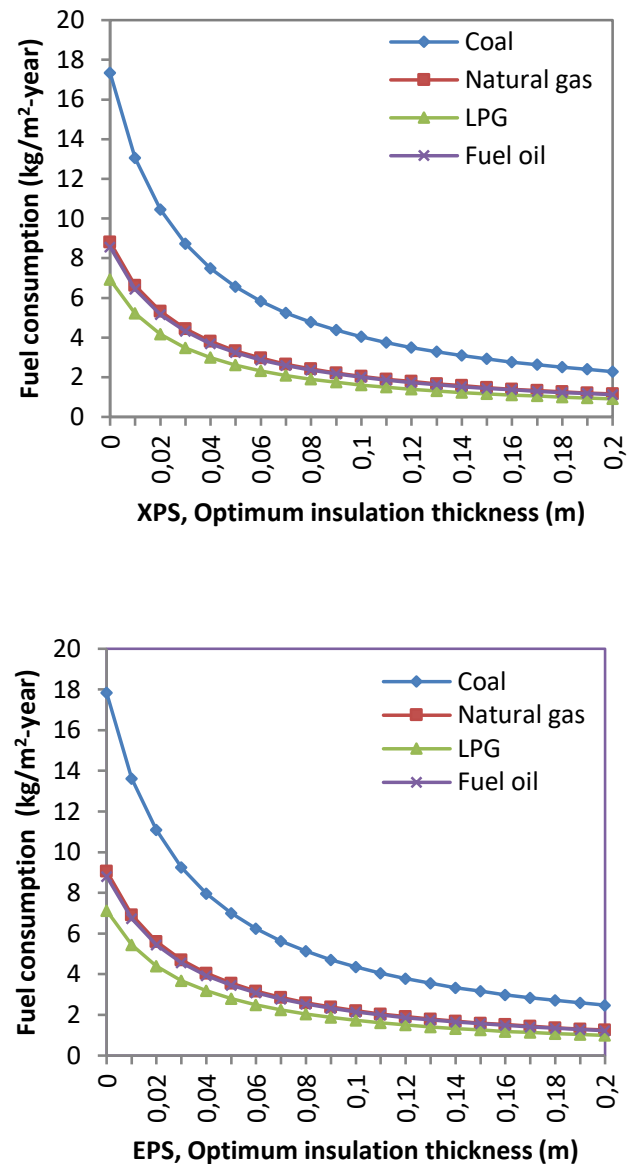

Although this decrease differs very little according to the type of insulation material, it becomes horizontal after some point. It was observed that when insulation was applied, $\mathrm{CO}_{2}$ rates could decrease by $80-90 \%$.
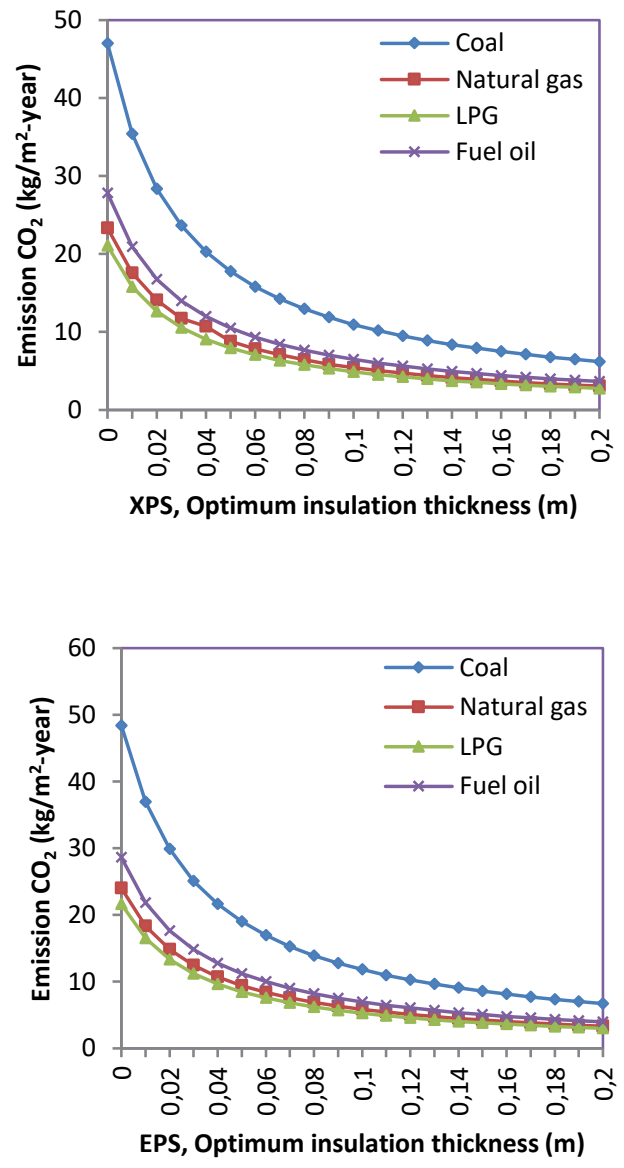

Figure 5. Fuel consumption and emissions. 
The payback period is very short, even though it changes depending on the fuel and the insulation material of the insulation costs. The system amortises itself in a short time and contributes to less fuel use. This is very important in a period when the fuel and energy costs are increasing every day.

The saving amount obtained is higher when LPG is used as fuel because the energy cost required to heat a unit area for LPG is higher than other fuels. The amount of savings trend to increase with increasing optimum insulation thickness. The same trend has been observed in the previous literature (Küçüktopçu and Cemek, 2018).

\section{Conclusions and Recommendations}

In parallel with population growth in Turkey, energy consumption is also increasing, and it is important that energy demand can be met from domestic sources. It is of great importance to use energy efficiently as well as meeting energy needs from domestic sources. Assessment of the potential for savings and reducing losses, especially in sectors where energy consumption is high, will reduce energy costs. Along with poultry farming being one of the industries growing rapidly in Turkey and the world, recently, the use of insulation systems in indoor farm areas to ensure proper physical conditions increases the quality and efficiency of production. In this study, optimum insulation thickness, energy-saving, and payback times were calculated on the outer walls of the buildings to ensure efficient use of energy in poultry sector buildings in Bandirma. The amount of savings and payback period vary between 17.75- 122 $\$ / \mathrm{m}^{2}$ and 1.72-1.20 years, respectively. It was calculated that a reduction by $80-90 \%$ in $\mathrm{CO}_{2}$ emissions could be achieved when optimum insulation thickness was applied.

However, insulation is a whole not only with the exterior of the building, but also with the roof, terrace and window. For this reason, insulation should be applied by considering the whole building in accordance with the relevant regulations. If the insulation applications are not carried out in accordance with the rules specified in the regulations and standards, the energy consumption for heating and cooling is higher than expected. It is important that the applications are carried out by competent people and carefully supervised.

\section{References}

Alsayed, MF., Tayeh, RA. (2019). Life cycle analysis for determining optimal insulation thickness in Palestinian buildings. Journal of Building Engineering 22, 101-112.

Arıtürk, E., Ergün, A., Yalçın, S. (1986). The relationship between poultry and environmental temperature. Lalahan Zoot. Arast. Enst. Derg. 26 (1-4) 42-52.

Axaopoulos, I., Axaopulos, P., Panayiotou, G., Kalogirou, S., Gelegenis, J. (2015). Optimal economic thickness of various insulation materials for different orientations of external walls considering the wind characteristics. Energy 90939 952.

Büyükalaca, O., Bulut, H., Yılmaz, T. (2001). Analysis of variable-base heating and cooling degree-days for Turkey. Appl Energy. 69(4): 269-83.

Bolattürk, A. (2008). Optimum insulation thicknesses for building walls with respect to cooling and heating degreehours in the warmest zone of Turkey. Building and Environment 43, 1055-1064.
Christenson, M., Manz, H., Gyalistras, D. (2006). Climate warming impact on degree-days and building energy demand in Switzerland. Energy Convers Manag 47 (6):67186.

De Rosa, M., Bianco, V., Scarpa, F., Tagliafico, L.A. (2014). Heating and cooling building energy demand evaluation; a simplified model and a modified degree days approach. Appl energy 128:217-29.

Eto, JH. (1988). On using degree-days to account for the effects of weather on annual energy use in Office building. Energy Build 12(2):113-27.

Hasan, A. (1999). Optimizing insulation thickness for buildings using life cycle cost. Applied Energy 63(2), 115-124.

Kaynakl1, O. (2008). A study on residential heating energy requirement and optimum insulation thickness. Renewable Energy 33, 1164-1172.

Küçüktopçu, E., Cemek, B. (2018). A study on environmental impact of insulation thickness of poultry building walls. Energy 150, 583-590.

Kürekçi, NA. (2016). Determination of optimum insulation thickness for buildings walls by using heating and cooling degree-day values of all Turkey's provincial centers. Energy and Buildings 119, 197-213.

Liu, X., Chen, Y., Ge, H., Fazio, P., Chena, G., Guoda, X. (2015). Determination of optimum insulation thickness for building walls with moisture transfer in hot summer and cold winter zone of China. Energy and Buildings 109, 361368.

Matzarakis, A., Balafoutis, C. (2004). Heating degree-days over Greece as an index of energy consumption. Int J Climatol 24(14):1817-28.

Özdemir, E., Poyraz, Ö. (1997). Insulation of poultry houses, Lalahan Zoot. Aras. Enst. Derg. 37(2) 91-108.

Rakshit, D., Muddu, D.M. Gowda, A.J. Robinson, A.B. (2021) Optimisation of retrofit wall insulation: An Irish case study. Energy and Buildings 235, 110720.

Rosti, B., Omidvar, A., Monghasemi, N. (2020). Optimal insulation thickness of common classic and modern exterior walls in different climate zones of Iran. Journal of Buildings Engineering 27, 100954.

Sabapathy, K.A., Gedupudi, S. (2020). On the influence of concrete-straw-plaster envelope thermal mass on the cooling and heating loads for different climatic zones of India. Journal of Cleaner Production 276, 123-117.

Şişman, N., Kahya, E., Aras, N., Aras, H. (2007). Determination of optimum insulation thicknesses of the external walls and roof (ceiling) for Turkey' different degree-day regions. Energy Policy 35,5151-5155.

Uçar, A., Balo, F. (2010). Determination of the energy savings and the optimum insulation thickness in the four different insulated exterior walls. Renewable Energy 35, 88-94.

Uçar, A., Usame Dumrul, M. (2019). Determination of optimum insulation thickness and energy saving analysis according to heating and cooling loads for exterior walls of a house in Malatya. European Journal of Science and Technology 16, 740-749.

Internet,2019http://www.canakkalegaz.com.tr/turkish.

Internet, 2020a; http://www.dosider.org, Fuel prices.

Internet, 2020b; http://www.izocam.com.tr, Unit Prices.

Internet, 2020c; The Central Bank of the Republic of Turkey (TCMB), http://www.tcmb.gov.tr/

Internet, 2020d; Turkish Statistical Institute (TUIK), http://www.tuik.gov.tr/ 